Available online at : http://journal.unj.ac.id/unj/index.php/gjik

Gladi : Jurnal Ilmu Keolahragaan 12 (02) 2021, 194-206

Permalink/DOI: https://doi.org/10.21009/GJIK.122.11

\title{
THE PERSPECTIVE OF CLINICAL CLERKSHIP STUDENTS ON HEALTH PROTOCOLS DURING THE COVID-19 PANDEMIC ON DAILY EXERCISE ACTIVITIES
}

\author{
Santi Anugrahsari ${ }^{1}$, Nining Parlina ${ }^{1}$, Muhammad Ikhwan Zein ${ }^{2}$, Ayatullah Muhammad Resza ${ }^{3}$, Suryadi ${ }^{1}$, \\ Hafid Abbas ${ }^{1}$ \\ ${ }^{1}$ Educational Management Department, Postgraduate Program, Universitas Negeri Jakarta. Jl. \\ Rawamangun Muka No 1, Jakarta 13220, INDONESIA. \\ ${ }^{2}$ Faculty of Sport Science, Universitas Negeri Yogyakarta. Jl. Colombo no 1, Yogyakarta 55281, \\ INDONESIA. \\ ${ }^{3}$ Physical Education and Training Department, Beijing Sport University, CHINA. \\ Corresponding author. Email santianugrah@gmail.com
}

\begin{abstract}
Physical exercise is essential to maintain human health. However, everybody has to apply the health protocols to prevent COVID-19 transmission during the pandemic. There is no exception; it is also applied for Clinical Clerkship Students who undergo the learning process at the Teaching Hospital. Unfortunately, no research provides a perspective on health protocol during the COVID-19 pandemic on daily exercise activities. This study aims to research the sports activities of Clinical Clerkship Students, measure knowledge about distance when exercising according to the protocol from the Ministry of Health, and describe their opinion regarding health protocols. This research conducted a mixed-method experiment that studies twenty-eight Clinical Clerkship Students. The type of sport and its frequency were evaluated using the International Physical Activity Questionnaire (IPAQ) short form. The enhancement of participants- knowledge after watching the video and sport activity were studied descriptive quantitatively. Meanwhile, their opinion on the health protocol was analyzed qualitatively. The participants' Physical Activity Categories were 25\% low, 50\% moderate, and $25 \%$ high. The results showed that low and high IPAQ Catagories have a higher video post-test score, but there was no correlation. More than $75 \%$ of the students understand the contents of health protocols during exercise. We conclude that half of Clinical Clerkship Students have a moderate physical activity category and know about distance when exercising through educational videos and believe that maintaining health during a pandemic by exercising is necessary as long as they adhere to health protocols.
\end{abstract}

Key Words: Clinical Clerkship Student, Health Protocol, COVID-19 Pandemic, Sport, Daily Exercise activity

\section{INTRODUCTION}

The SARS Cov2 virus transmission

has made human movement restrictions worldwide (Piccoli, Dzankic, and Ruedin 2021). Everybody has to stay at home, work from home and do distance learning to prevent the virus spread (Pokhrel and Chhetri 2021). However, this restriction also affects daily human life because it decreases physical activity and increases the risk of gain weight $(\mathrm{Pu}$ et al. 2020). To reduce the risk of gaining weight during the pandemic, human has to get enough sleep, 
Gladi Jurnal Ilmu Keolahragaan, 12 (02), June- 195

Santi Anugrahsari, Nining Parlina, Muhammad Ikhwan Zein, Ayatullah Muhammad Resza, Suryadi, Hafid Abbas ${ }^{1}$

avoid snacking after dinner, adopt a diet, get a handle on stress, and maintain physical exercise (Zachary et al. 2020).

Besides maintaining a healthy life with physical exercise (Mishra and Rani 2020), peoples also have to maintain physical distancing to avoid the spread of the SARS Cov2 virus (Goniewicz and Khorram-Manesh 2021). A combination of physical activity and physical distancing is good to prevent the infected risk (Dominski and Brandt 2020). Exercise induces a systemic response, leading to the activation of the immune system (Geta, Dliss, and Abdul 2021). Uncontrolled activation of the immune system can increase the risk of infection or cause inflammatory processes in the airways (Liu et al. 2020)(Shaw et al. 2018). Moderate exercise and if done more often can help the body get better, but if done inadequately, it can cause many disorders that lead to malfunction of the immune system (Ade, Pelana, and Setiakarnawijaya 2021; Scudiero et al. 2021).

Unlike most students who stay at home and do distance learning during the COVID-19 pandemic, Clinical Clerkship Students have to do the learning activities at the Teaching Hospital. Unfortunately, no research provides a Clinical Clerkship Students perspective on health protocol during the COVID-19 pandemic on daily exercise activities. Besides implementing the health protocol, the student has to conduct a physical activity, such as sport, to maintain their health and fitness. Furthermore (Hengki, Iswana, and Fahritsani 2021), they also have to apply physical distancing in daily activity from a video produced by the Ministry of Health of the Republic of Indonesia. In this study, the Clinical Clerkship Students' level of understanding of physical activity, physical distancing, and injury prevention knowledge was measured in mix-method research. Therefore, this study can recommend appropriate physical activity and physical distancing suitable for the Clinical Clerkship Student.

\section{METHODS}

This study conducted mixed-method research. Twenty-eight Clinical Clerkship Students at the teaching hospital in North Jakarta-Indonesia participated in this study. In the study, students learn the covid-19 prevention protocol from a two-minute 
Gladi Jurnal Ilmu Keolahragaan, 12 (02), June- 196

Santi Anugrahsari, Nining Parlina, Muhammad Ikhwan Zein, Ayatullah Muhammad Resza, Suryadi, Hafid Abbas ${ }^{1}$

video produced by the Ministry of Health of the Republic of Indonesia. The video delivered the protocol during physical activity, such as wearing masks, maintaining physical distancing, staying away from the crowd, and managing personal hygiene after the activity. After studying the two-minute video, the students' comprehension was reviewed by filling out an online questionnaire. The online questionnaire consisted of the International Physical Activity Questionnaire (August 2002), which shorted the last seven days Self-

Administered Format www.ipaq.ki.se and Google Forms (https://docs.google.com/forms). The questionnaire evaluated several aspects: knowledge on safe distancing during exercise, physical activity during the pandemic, and self-perception on covid-19 health protocol. The knowledge on safe distancing and physical activity was analyzed quantitively. Meanwhile, selfperception was evaluated qualitatively. The questionnaire details are presented in table 1.

Table 1. Detail of Questionnaire

\begin{tabular}{|c|c|}
\hline Statement & types $\begin{array}{l}\text { Question } \\
\text { ton }\end{array}$ \\
\hline \multicolumn{2}{|l|}{ Safe distancing while exercising } \\
\hline Safe distancing recommendation while bicycling & $\begin{array}{l}\text { Multiple } \\
\text { choices }\end{array}$ \\
\hline Safe distancing recommendation while walking & $\begin{array}{l}\text { Multiple } \\
\text { choices }\end{array}$ \\
\hline Safe distancing recommendation while running & $\begin{array}{l}\text { Multiple } \\
\text { choices }\end{array}$ \\
\hline Safe distancing recommendation while side by side position & $\begin{array}{l}\text { Multiple } \\
\text { choices }\end{array}$ \\
\hline \multicolumn{2}{|l|}{ Experience of physical activity during the pandemic } \\
\hline Low-intensity physical activity & Open question \\
\hline Vigorous-intensity physical activity & Open question \\
\hline Frequency of physical activity (frequencies per week) & Open question \\
\hline \multicolumn{2}{|l|}{ Self-Perceptions of the Subjects } \\
\hline $\begin{array}{l}\text { Acceptance of physical activity with health protocol during the } \\
\text { pandemic }\end{array}$ & Likert scale \\
\hline $\begin{array}{l}\text { Self-perception on the self-understanding of COVID-19 health } \\
\text { protocol }\end{array}$ & Likert scale \\
\hline
\end{tabular}

The data was then analyzed by descriptive statistics. 
Gladi Jurnal Ilmu Keolahragaan, 12 (02), June- 197

Santi Anugrahsari, Nining Parlina, Muhammad Ikhwan Zein, Ayatullah Muhammad Resza, Suryadi, Hafid Abbas ${ }^{1}$

\section{RESULTS}

Some of the research results obtained are: characteristics of respondents, results of IPAQ ( to finding out about the kinds of physical activities that subject do as part of their everyday lives (The questions ask about the time spent being physically active in the last seven days). During the pandemic, low and vigorous activities were carried out during pandemic, frequency of exercise during pandemic (Table 2). Level of knowledge of Sports videos with New Habits from the Ministry of Health regarding sports distancing ( Table 3). Clinical Clerkship perspective on sports safety according to the protocol, understanding of the protocol when exercising, and respondents' opinions regarding the appropriate types of exercise during pandemic.

Of the 28 Clinical Clerkship Students who answered the questionnaire, most were aged 23 to 24 years. They carried out activities ranging from low activities such as stretching to vigorous activities (Fig. 1 and 2).

Table 2. Characteristics of the subjects with total respondents of 28 students

\begin{tabular}{lcc}
\hline Characteristics & $\begin{array}{c}\text { Respondents } \\
\text { (n) }\end{array}$ & $\begin{array}{c}\text { Percentage } \\
(\%)\end{array}$ \\
\hline Age & & \\
\hline $21-22$ & 16 & 14.28 \\
$23-24$ & 8 & 57.14 \\
$25-26$ & & 28.57 \\
\hline Sex & 14 & \\
Male & 14 & 50 \\
Female & & 50 \\
\hline Frequency of exercise & 3 & \\
pandemic & 12 & 10.71 \\
1 time /week & 10 & 42.85 \\
2 times/week & 3 & 35.71 \\
3 times/week & & 10.71 \\
4 times/week & & \\
\hline The International Physical & 7 & 25 \\
Questionnaire & 14 & 50 \\
$\quad$ Low & 7 & 25 \\
$\quad$ Moderate & & \\
$\quad$ High &
\end{tabular}


Gladi Jurnal Ilmu Keolahragaan, 12 (02), June- 198

Santi Anugrahsari, Nining Parlina, Muhammad Ikhwan Zein, Ayatullah Muhammad Resza, Suryadi, Hafid Abbas ${ }^{1}$

Table 3. Correlation IPAQ Score and Evaluation Score

\begin{tabular}{llllll}
\hline IPAQ/Evaluation & Question 1 & Question 2 & Question 3 & Question 4 & Average \\
\hline Low & $85,71+14,28$ & 100 & $85,71+14,28$ & 100 & $92,85+7,14$ \\
\hline Moderate & $71,42+12,52$ & 100 & $78,57+11,38$ & 100 & $87,50+5,71$ \\
\hline High & $85,71+14,28$ & 100 & $85,71+14,28$ & 100 & $92,85+7,14$ \\
\hline
\end{tabular}

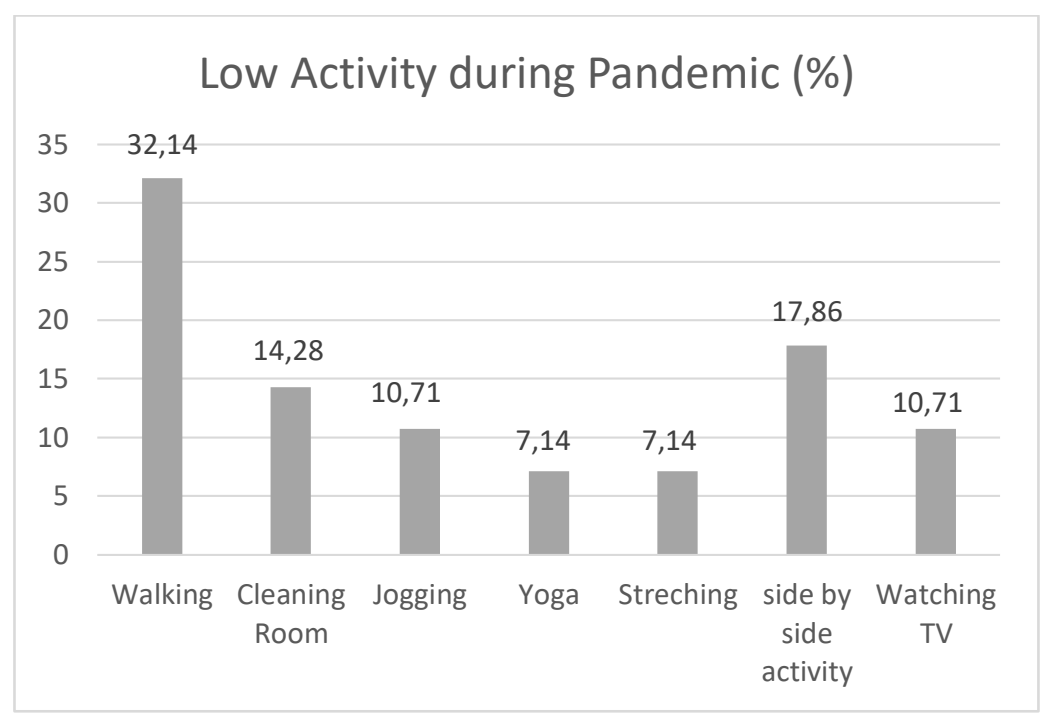

Figure 1. Low activity during Pandemic.

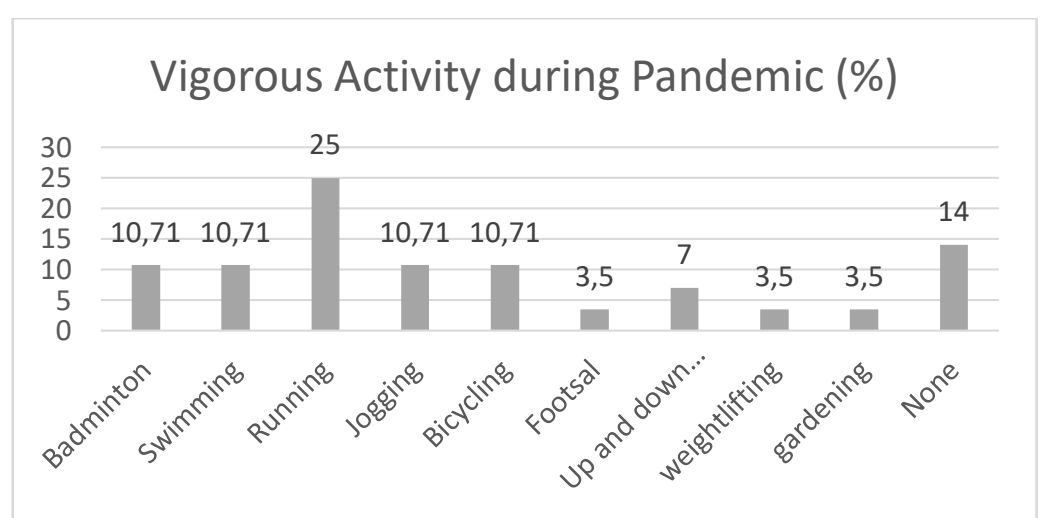

Figure 2. Vigorous Activity during Pandemic. 
Gladi Jurnal Ilmu Keolahragaan, 12 (02), June- 199

Santi Anugrahsari, Nining Parlina, Muhammad Ikhwan Zein, Ayatullah Muhammad Resza, Suryadi, Hafid Abbas ${ }^{1}$

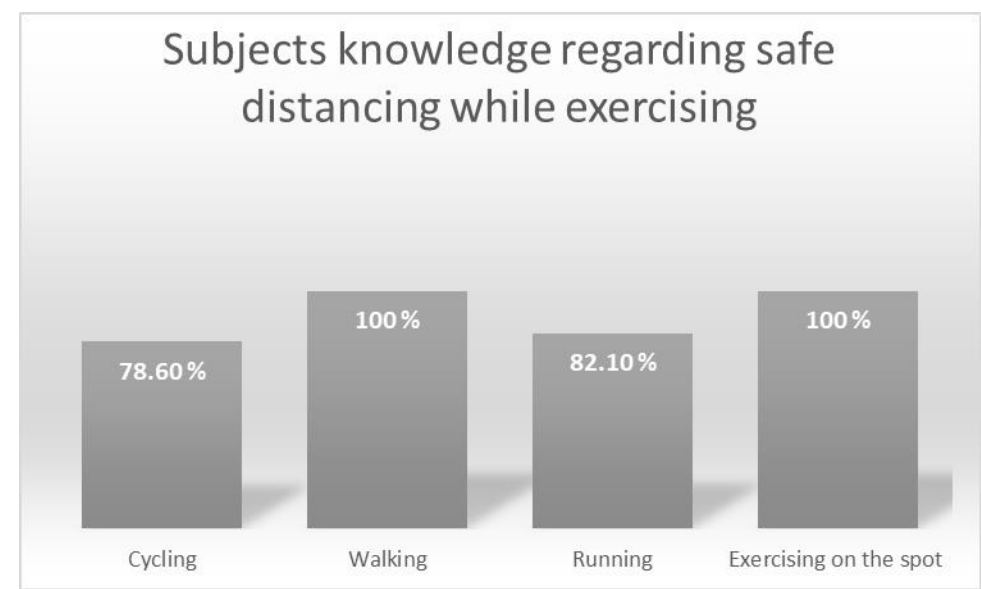

Figure 3. Students' knowledge on safe distancing while exercising.

Subjects responses to question regarding Acceptance of physical activity with health protocol during the pandemic

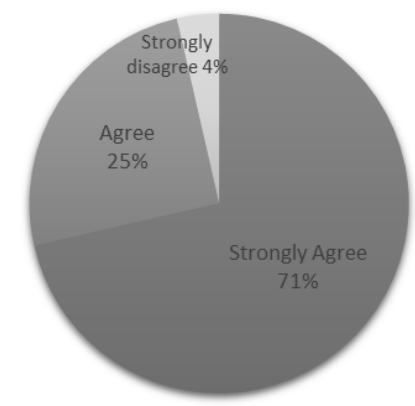

Figure 4. Students' responses to question on physical activity with health protocol during pandemic.

Most of the clinical students $(71.4 \%)$ strongly agree that exercise with health protocols is safe. Meanwhile 3.6\% did not do sports activity during pandemic, even with health protocols. 
Gladi Jurnal Ilmu Keolahragaan, 12 (02), June- 200

Santi Anugrahsari, Nining Parlina, Muhammad Ikhwan Zein, Ayatullah Muhammad Resza, Suryadi, Hafid Abbas ${ }^{1}$

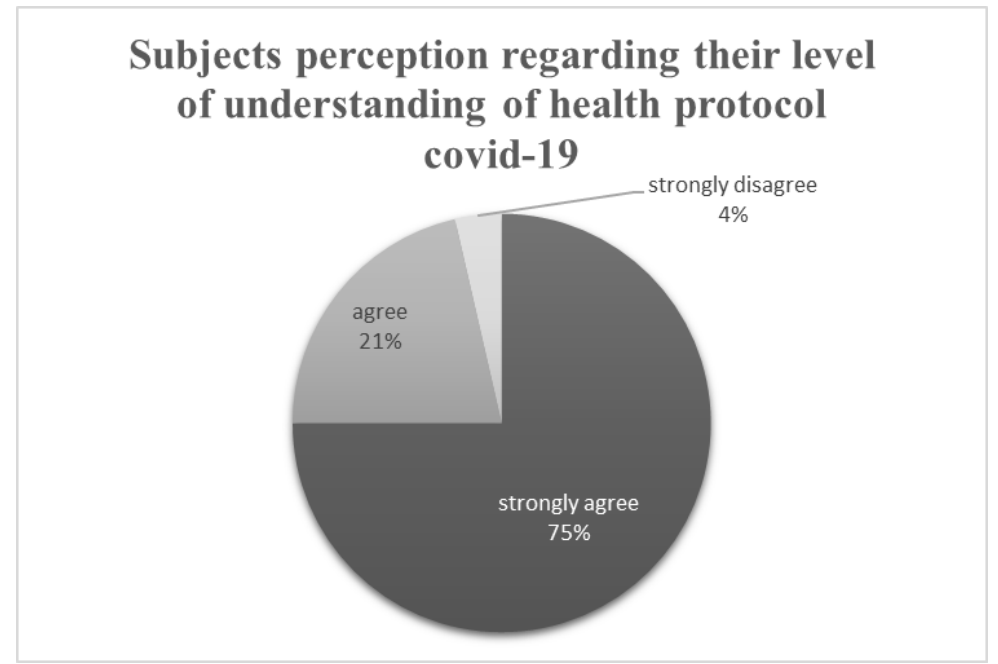

Figure 5. Student perception on their understanding level of COVID-19 health protocol

The result shows that $75 \%$ of respondence or 21 students experienced the COVID-19 health protocol, $21.4 \%$ of respondence or six students understood the protocol, and the rest didn't understand the health protocol.

\section{DISCUSSION}

This study is dominated by $23-24$ years old respondents whose physical activity was categorized into $25 \%$ low, $50 \%$ moderate, and $25 \%$ high. Since the IPAQ is students' physical activity in the last seven days, it was also identified into four types (1) Vigorous physical activities, like heavy lifting, digging, aerobics, or fast bicycling, (2) Moderate physical activities, such as carrying light loads, bicycling at a regular pace, or doubles tennis (not including walking), (3) Walking, that includes at work and home, travel from place to place, solely for recreation, sport, exercise, or leisure, (4) Sitting on weekdays which inclusive time spent at work, at home, while doing course work and during leisure time. It may include time spent sitting at a desk, visiting friends, reading, sitting, or lying down to watch television.

Besides IPAQ, this study also conducted open questions on the exercise frequencies. Here, most Clinical Clerkship 
Gladi Jurnal Ilmu Keolahragaan, 12 (02), June- 201

Santi Anugrahsari, Nining Parlina, Muhammad Ikhwan Zein, Ayatullah Muhammad Resza, Suryadi, Hafid Abbas ${ }^{1}$

Students exercise 2-3 times per week. However, their exercise or physical activity was not implemented the WHO recommendations, which are 150 minutes the moderate intensity of aerobic for five times per week, 30 minutes to 75 minutes of heavy intensity exercise for 2-3-times per week, and 20 minutes of potential exercise to conduct a healthy lifestyle. Moreover, they must start the exercise activity by themselves and become a model for the community-or patient. The sports vary from walking, jogging, cycling, swimming, games, gymnastics, yoga, etc. The sports types are selected based on the students' interests and capacity. It is also essential to do various exercises to stimulate the body muscles and avoid injuries, for example, a variation of jogging with swimming to train the lower and upper muscles.

The Clinical Clerkship Students have appropriate knowledge on minimum distances while exercising, walking, cycling, and running, side by side. Low and High IPAQ has a high score of evaluation of this post-test video. Still, there was no correlation between IPAQ and evaluation result (Corr coeficient: 0.00, Sig (2-tailed): 1.00) (Spearman Correlation) (Table 3). As one of the prospective medical personnel, the Clinical Clerkship Student educates the community to maintain physical distancing during group sports activity. COVID-19 is an infectious disease that is easily transmitted from one person to another. The spread is like other respiratory diseases. A droplet, splash of saliva, or mucus from an infected person is released when sneezing or coughing. When it comes to other people, especially the face, this droplet can cause that person to become infected because the virus can enter the body through the nose, mouth, and even the eye socket. According to WHO, the droplets can reach one meter. Therefore, the recommended safe distance between one person and another is two meters. Accordingly, the physical distancing knowledge during the exercise is essential to prevent the Coronavirus spread.

The opinions of several clinical clerkships students are summarized as follows: "Exercise must be carried out in the pandemic era for a healthy and fit body to fight the coronavirus by consuming a balanced nutritious diet and exercise. Exercise according to their respective capacities. Don't overexert yourself'”'. 


\section{Gladi Jurnal Ilmu Keolahragaan, 12 (02), June- 202}

Santi Anugrahsari, Nining Parlina, Muhammad Ikhwan Zein, Ayatullah Muhammad Resza, Suryadi, Hafid Abbas ${ }^{1}$

Therefore, it is essential to maintain a lifestyle and diet. Diet alone is not enough to burn belly fat. It would be best companied by exercising regularly at least 30 minutes per day - the fascinating fact in the clinical clerkship students' interviews on the types of sports they do. "During this pandemic, where my activities were minimal, I decided to exercise every day by doing a 60-second Russian twist, 60 seconds bicycle crunches, 60 seconds of heels touch, and 60 seconds of plank".

The Russian twist moves the abdominal muscles and the leg muscles. We can use a light dumbbell or a bottle filled with sand. How to do a Russian twist: sit on the mat, bend the knees and hips 90 degrees and keep your feet flat on the floor, hold a barbell or other tool as a weight, leaning back, rotate the body left and right using the abdominal muscles.

To burn fat effectively with the bicycle crunch move. This movement is quite exhausting because it makes the abdominal muscles tighter. A bicycle crunch is precisely the movement of the legs like pedaling a bicycle, but the body will lie flat on the floor. How to do a bicycle crunch: lay down on the mat, place the hands behind the head or by your ears, raise the head slightly and do not touch the mat, raise both feet so that they do not touch the mat, move both legs like pedaling a bicycle, bend the left leg, move the right elbow until it touches the left knee, and do the same for the other side, do it for 35 seconds or 12 times (6 times on the left side and six times the right side), repeat three sets.

A powerful exercise movement to eradicate abdominal fat is heel touch. This movement is relatively easy to do, but the results are very satisfying if done regularly. How to do heel touch: lie on your back on the mat, bend the legs with your knees above, raise the shoulders a little, not too high, then alternately touch the left and right heels, do it for 35 seconds or 12 times (6 times on the left side and six times the right side), repeat three sets. The plank is an everyday movement that is very effective for shrinking the stomach and strengthening the core muscles of the abdominals. It looks easy, but it takes extra effort, and the results you get will be very satisfying if we do this efficiently and regularly. The following is how to do the plank movement: lie face down on the mat, put both palms on the floor, push yourself up and use your toes for 
Gladi Jurnal Ilmu Keolahragaan, 12 (02), June- 203

Santi Anugrahsari, Nining Parlina, Muhammad Ikhwan Zein, Ayatullah Muhammad Resza, Suryadi, Hafid Abbas ${ }^{1}$

support, keep your head, neck, and back in a straight and stable line, hold for a minimum of 30 seconds.

For the general public, the recommended types of sports during a pandemic are individual and can be done at home without involving many people. Thus, the risk of transmission of the coronavirus can be reduced. These include (1) Jumping Jack. This type of exercise can be done anywhere and anytime. There is no need for special equipment either. Enough with comfortable sports shoes. The jumping jack's benefit is to reduce the risk of heart disease; strengthens the thighs, calves, gluteus, and shoulders. Stand with your legs straight and hands at our sides, jump while spreading your legs and hands up, almost touching. Jump again while lowering both hands and returning the legs to their original position. (2) Jump rope. Like jumping jacks, this type of sport, also known as skipping, is done by jumping. The difference is that it takes equipment in the form of a special rope for this sport. Jump rope can improve body coordination, maintain heart health, strengthens leg muscles. Stand straight with both hands grasping the rope handle. The rope should hang behind the legs, swing the strap with your palms and wrists over your head and jump when the rope swings toward your feet. (4) Sit Up. Sit-ups are a simple exercise but must be done in the right way. There are several ways to do sit-ups. Choose the most comfortable. Sit Up can strengthen the abdominal muscles, improves posture, increases flexibility. While lying down, bend your knees with our feet flat on the floor. The width of the feet is equal to the hips. Both hands hold the back of the head at an angle. While exhaling, push your upper body up until it is upright. While inhaling, return to the original lying position. When doing sit-ups, the view should be straight. (5) Yoga. There are many yoga movements as a sport of choice during a pandemic. Every move has a different level of ease. We believe that Yoga can maintain physical and psychological fitness and improve posture.

The WHO recommends doing 150 minutes of moderate-intensity physical activity or 75 minutes each week, or a combination of both. This recommendation can still be achieved even at home, without special equipment, and with limited space. Some tips on staying active and reducing sedentary behavior while at home are short active breaks during the day. Brief bouts of 


\section{Gladi Jurnal Ilmu Keolahragaan, 12 (02), June- 204}

Santi Anugrahsari, Nining Parlina, Muhammad Ikhwan Zein, Ayatullah Muhammad Resza, Suryadi, Hafid Abbas ${ }^{1}$

physical activity add to weekly recommendations. We can use the suggested exercises as inspiration to be active every day. These activities include dancing, playing with children, and doing household chores such as cleaning and gardening. Even in a small space, take a walk or walk on the spot. Take a walk around the house, talking rather than sitting. If you decide to go out for a walk or exercise, make sure to keep a distance of at least 1 meter from other people. Spend less time standing up if possible. Ideally, try to stop time sitting and lying down every 30 minutes. Consider setting up a standing table using a tall table or stacking books or other materials to continue working while standing. During your free time, focus on cognitively stimulating activities, such as reading, board games, and puzzles. Meditation and deep breathing can help you stay calm (World Health Organization 2020).

Exercise has been shown to improve fitness and benefit from increasing body immunity. However, its application during this pandemic must still pay attention to several things to prevent the transmission of COVID-19. Sports are recommended to be done individually (at home or private property such as terraces, balconies, yards) by applying physical distancing. As much as possible, reduce exercise in public areas where there are large crowds not to keep your distance and touch the surfaces of public facilities. Some recommendations for sports that can be done individually at home include cardiovascular/aerobic exercise with jumping jacks, jumping rope, going up and downstairs, running in place, stair climbing, lifting and carrying groceries, chair squats, or using home gym equipment like a treadmill or stationary bike. Muscle strength training can be done with sit-ups or crunches (half sit-ups) to train the abdominal muscles, planks to train the core muscles (torso), push-ups to train the chest muscles and upper extremities. We can be using mobile technologies such as telephone applications and wearable sensors to encourage movement. Exercise can also be done through videos, YouTube, or online classes, for example, Yoga, aerobics, pilates, Taichi, and others (Woods et al. 2020).

Clinical clerkship students are prospective doctors in the future who are obliged and responsible for the fate of health. This is important concerning education to the public, especially in sports, 
Gladi Jurnal Ilmu Keolahragaan, 12 (02), June- 205

Santi Anugrahsari, Nining Parlina, Muhammad Ikhwan Zein, Ayatullah Muhammad Resza, Suryadi, Hafid Abbas ${ }^{1}$

how they maintain their own health by exercising during this pandemic, and how they provide education about maintaining distance and health protocols to prevent the spread of the disease COVID-19 virus. We recommend further research with a broader range of subjects to know health protocols can reach more people.

\section{CONCLUSION}

A half of Clinical Clerkship Students have a moderate physical activity category by IPAQ Short Form. They also know very well about distance when exercising through educational videos. They believe that maintaining health during a pandemic by exercising is necessary as long as they adhere to health protocols. Our Suggestion is the ultimate precaution necessary when exercising is to keep physical distance as recommended. Exercise is beneficial for physical and mental health. However, its implementation during this pandemic still has to be in a way that is safe and appropriate for reduce the massive spread of COVID-19.

\section{Acknowledgment}

We would like to take this opportunity to thank you for your effort and expertise as a reviewer, Mrs. Mutia Delina, MSi, Ph.D. Your help enabled us to meet the scheduled time and to maintain the standards of peerreviewed.

\section{REFERENCES}

Dominski, Fábio Hech, and Ricardo Brandt. 2020. "Do the Benefits of Exercise in Indoor and Outdoor Environments during the COVID-19 Pandemic Outweigh the Risks of Infection?" Sport Sciences for Health.

Dude, Argi, Ramdan Pelana, and Yasep Setiakarnawijaya. 2021. "Evaluation of Learning Physical Education in the Covid-19 Pandemic." Gladi: Jurnal Ilmu Keolahragaan 12(01): 55-61.

Geta, septiadi, Firmansyah Dliss, and Sukur Abdul. 2021. "The Effect of Online Learning and Student Motivation During the Covid-19 Pandemic." Gladi: Jurnal Ilmu Keolahragaan 12(01): 62-72.

Goniewicz, Krzysztof, and Amir KhorramManesh. 2021. "Maintaining Social Distancing during the COVID-19 Outbreak." Social Sciences 10(1): 1-7.

Hengki, Hengki Kumbara, Bayu Iswana, and Husni Fahritsani. 2021. "A Profesionalisme Guru Pjok Ditinjau Dari Kinerja Pedagogik (Studi Persepsi Siswa Di Lingkungan Sma/Smk Negeri Se Kecamatan Suak Tapeh Banyuasin)." Gladi: Jurnal Ilmu 
Santi Anugrahsari, Nining Parlina, Muhammad Ikhwan Zein, Ayatullah Muhammad Resza, Suryadi, Hafid Abbas ${ }^{1}$

Keolahragaan 12(01): 9-16.

Liu, Kui et al. 2020. "Clinical Characteristics of Novel Coronavirus Cases in Tertiary Hospitals in Hubei Province." Chinese medical journal.

Mishra, Rakhi, and Ruchika Rani. 2020. "Healthy Life Style Practices to Combat COVID-19 Pandemic- A Mini Review." IP Indian Journal of Immunology and Respiratory Medicine 5(3): 137-40.

Piccoli, Lorenzo, Jelena Dzankic, and Didier Ruedin. 2021. "Citizenship, Migration and Mobility in a Pandemic (CMMP): A Global Dataset of COVID-19 Restrictions on Human Movement." PLoS ONE 16(3 March): 1-10.

Pokhrel, Sumitra, and Roshan Chhetri. 2021. "A Literature Review on Impact of COVID-19 Pandemic on Teaching and Learning." Higher Education for the Future 8(1): 133-41.

$\mathrm{Pu}$, Bo, Lu Zhang, Zhiwei Tang, and Yanjun Qiu. 2020. "The Relationship between Health Consciousness and Home-Based Exercise in China during the Covid-19 Pandemic." International Journal of
Environmental Research and Public Health 17(16): 1-18.

Scudiero, Olga et al. 2021. "Exercise, Immune System, Nutrition, Respiratory and Cardiovascular Diseases during COVID-19: A Complex Combination." International Journal of Environmental Research and Public Health.

Shaw, David M., Fabrice Merien, Andrea Braakhuis, and Deborah Dulson. 2018. "T-Cells and Their Cytokine Production: The Anti-Inflammatory and Immunosuppressive Effects of Strenuous Exercise." Cytokine.

Woods, Jeffrey A. et al. 2020. "The COVID-19 Pandemic and Physical Activity." Sports Medicine and Health Science.

World Health Organization. 2020. "Stay Physically Active during SelfQuarantine." Worl Health Organization (WHO).

Zachary, Zeigler et al. 2020. "SelfQuarantine and Weight Gain Related Risk Factors during the COVID-19 Pandemic." Obesity Research and Clinical Practice. 